\title{
ZIARAH KUBRA DI PALEMBANG: ANTARA KESADARAN RELIGI DAN POTENSI EKONOMI
}

\author{
KUBRA PILGRIMAGE IN PALEMBANG : \\ BETWEEN RELIGIOUS AWARENESS AND ECONOMIC POTENTIAL
}

\author{
Firdaus Marbun \\ Balai Pelestarian Nilai Budaya (BPNB) Sumatera Barat \\ Jl. Raya Belimbing No 16 A Kuranji Kota Padang \\ E-mail: marbunfirdaus@gmail.com
}

\begin{abstract}
Abstrak
Bagi umat beragama di Indonesia, ziarah masih merupakan kegiatan penting yang hingga kini masih tetap dipertahankan. Berbagai motivasi yang menyertai seperti barokah dan perolehan biasanya menjadi pendorong seseorang untuk melaksanakan kunjungan ke makam orang yang sudah meninggal. Bahkan tradisi ini kemudian berkembang untuk tujuan-tujuan yang lebih besar seperti mempertahankan identitas dan menjaga eksistensi keagamaan. Ziarah kubra adalah salah satu tradisi ziarah yang rutin dilaksanakan umat Islam di Palembang. Ziarah ini dilakukan setiap akhir bulan Sya'ban atau menjelang umat Islam berpuasa. Menariknya, tradisi ini diikuti ribuan peserta yang semuanya laki-laki dan tidak hanya dari dalam negeri, tapi juga dari luar negeri. Ziarah ini bahkan dijadikan sebagai even pariwisata yang masuk dalam kalender tahunan. Penelitian ini bertujuan mengungkap motivasi masyarakat Islam dalam mendorong perubahan ruahan menjadi ziarah kubra. Selain itu penelitian ini juga ingin mengungkap potensi ekonomi pasca penetapan ziarah kubra sebagai even pariwisata daerah yang rutin dilaksanakan. Dengan menggunakan metode kualitatif melalui observasi dan wawancara, penelitian ini menemukan bahwa selain memdapatkan barokah dan perolehan, emosi keagamaan berperan meningkatkan solidaritas masyarakat muslim untuk mempertahankan makam dengan mengikuti ziarah rutin setiap tahun. Tradisi ini juga turut membantu ekonomi daerah dan berpotensi mendorong kesejahteraan masyarakat di masa yang akan datang khususnya dalam sektor pariwisata.
\end{abstract}

Kata kunci: Ziarah kubra, religi, emosi keagamaan, ekonomi

\begin{abstract}
For religious people in Indonesia, pilgrimage is an important activity which still be maintained till this day. "Baraka" and acquisition are usually motivations for them to visit the grave of the deceased. Even, this tradition then evolves for larger purposes such as to keep identity and existence of religion. Pilgrimage kubra is one of the pilgrim traditions which is implemented by Muslims in Palembang routinely. This pilgrimage is done every end of Sya'ban month or before fasting. Interestingly, this tradition is followed by thousands of participants who are all male and they come not only from domestic, but also from abroad. Even, this pilgrimage is become an annual tourism event. This study aims to reveal the motivation of Islamic society in encouraging the change of the bulk into a pilgrimage kubra. In addition, this research also wants to reveal the economic potential of post-pilgrimage pilgrimage as a regional tourism event that routinely implemented. Using qualitative methods through observation and interviews, the study found that in addition to obtaining "baraka" and acquisition,
\end{abstract}


religious emotions contributed to the solidarity of the Muslim community to defend the grave by following regular pilgrimage every year. This tradition also helps the local economy and has the potential to promote the welfare of the people in the future especially in the tourism sector.

Key words: Pilgrimage kubra, religion, religious emotion, economy

\section{PENDAHULUAN}

Subuh itu, sesaat setelah azan subuh berkumandang, satu persatu jemaah berdatangan ke Masjid Darul Muttaqien, tidak jauh dari pertigaan Jalan Slamet Ryadi dan Jalan Dr. M. Isa (Pasar Kuto), Palembang. Para pria dengan kopiah dan pakaian serba putih kemudian masuk setelah sebelumnya berwudhu, lalu sholat subuh berjamaah secara khusuk. Tidak ada kejadian yang istimewa waktu itu. Namun seiring sang fajar menunjukkan diri, para pria di Masjid tersebut semakin banyak, semua menggunakan warna pakaian yang sama, putih. Beberapa diantara pria tersebut ada yang membawa marawis, umbul-umbul, dan tidak ketinggalan di tengah jalan telah tersedia satu mobil (pick up) komando lengkap dengan pengeras suara. Sesaat setelah itu para pria tersebut, dengan dipimpin ulama mulai arak-arakan sambil mengumandangkan ayat-ayat Al-Quran, memenuhi jalan menuju pemakaman Gubah Duku. Hari itu memang saat dimulainya rangkaian ziarah kubra, ziarah ke makam ulama dan auliyah Palembang Darussalam.

Palembang, ibukota Provinsi Sumatera Selatan, merupakan salah satu kota penting dan punya sejarah panjang di Indonesia. Sejak dulu Palembang telah dikenal sebagai pusat perdagangan yang cukup maju, bahkan sebelumnya dipercaya sebagai pusat kerajaan besar nusantara Sriwijaya. Posisi Palembang yang dilalui oleh sungai Musi semakin strategis sebagai pusat perdagangan yang senantiasa ramai oleh kedatangan berbagai suku-suku bangsa di dunia. Baik hanya untuk tujuan berdagang, maupun untuk penyebaran agama. Interaksi antara bangsa ini kemudian memungkinkan berkembangnya berbagai tradisi dari latar belakang budaya bangsa yang berbeda.

Keberadaan keturunan Arab di Kota Palembang telah ada sejak sebelum kolonial masuk ke Indonesia. Sungai Musi sebagai jalur perdagangan mendorong berbagai suku bangsa hadir dan tinggal di Palembang termasuk keturunan Arab. Pada awalnya mereka datang sebagai pedagang lalu menyebarkan agama Islam. Kemampuan ekonomi yang mapan membuat mereka dapat tempat di hati para sultan di kesultanan Palembang pada masa itu. Posisi tersebut juga secara langsung mampu menciptakan dan mengembangkan agama dan adat budaya mereka dengan baik. Diterimanya agama Islam menjadi agama kesultanan menjadi contoh konkrit peran keturunan Arab di Palembang.

Selain itu, ada satu tradisi yang berkembang dan menjadi populer pada masa sekarang yakni ziarah. Ziarah, sesungguhnya bukan hal yang baru bagi masyarakat Indonesia. Namun, kedatangan komunitas Arab di Palembang telah membuat ziarah tersebut berbeda dari beberapa ziarah yang terjadi di daerah lain. Tradisi ziarah ini awalnya hanya ziarah biasa yaitu mengunjungi makam-makam keluarga, namun pada perkembangannya tradisi ini menjadi besar dengan 
melibatkan banyak orang dan dilaksanakan secara kontinu. Tradisi ini disebut dengan ziarah kubra.

Dikatakan kubra karena diikuti oleh ribuan bahkan puluhan ribu orang. Tradisi ini diadakan sekali setahun, biasanya seminggu menjelang bulan ramadhan. Ribuan orang bahkan puluhan ribu orang yang berkumpul melaksanakan kegiatan tidak hanya penduduk perkampungan Arab, tapi juga dari luar kota bahkan luar negeri. Para peserta biasanya mengadakan shalat berjamaah di masjid, long march dari satu makam ke makam yang lain sambil mendengungkan syiar-syiar Islam serta merayakan haul para habaib-habaib yang telah lebih dahulu meninggal. Keunikan tradisi ini tidak hanya pada jumlah peserta yang mencapai ribuan atau puluhan ribu tapi seluruh peserta yang terlibat adalah adalah laki-laki dari berbagai segmentasi usia serta menggunakan baju dan celana putih.

Menurut pengakuan masyarakat setempat, ziarah kubra telah berlangsung lama. Awalnya hanya ziarah keluarga, kemudian berkembang melibatkan masyarakat dari dalam dan luar negeri. Hingga kini, ziarah kubra telah melibatkan ribuan orang. Bahkan, Pemerintah Provinsi Sumatera Selatan telah menjadikan tradisi ini sebagai even pariwisata daerah yang masuk dalam kalender pariwisata provinsi. Penetapan ini disusul kemudian promosi yang massif yang mendorong masyarakat rela datang bukan hanya sekadar ziarah tapi juga berwisata. Hingga ketika acara ziarah kubra berlangsung, hotel-hotel tempat menginap penuh. Jalan-jalan di perkampungan Arab juga macet.

Tradisi ruahan yang hanya diikuti oleh anggota keluarga menjadi satu tradisi Kubra menjadi menarik diketahui. Apa yang mendorong masyarakat Kota Palembang khususnya komunitas Arab mengadakan acara ziarah kubra yang bahkan hingga melibatkan ribuan orang. Bahkan, akibat perubahan tersebut telah turut mendorong perekonomian Kota Palembang menjadi lebih bergairah. Tentu hal itu tidak disebabkan oleh peristiwa yang biasa-biasa saja atau pertambahan penduduk saja, tapi lebih dari itu. Perubahan itu bisa dimungkinkan karena aspek-asek religi atau hal lain.

Kajian ini bertujuan untuk menjelaskan aspek-aspek yang mendorong perubahan ruahan menjadi ziarah kubra yang melibatkan ribuan orang. Selain itu, penelitian ini juga bertujuan untuk menggali potensi ekonomi pasca populernya ziarah kubra di Kota Palembang. Hal ini penting untuk dapat memanfaatkan aktivitas-aktivitas religi menjadi wisata yang dapat diandalkan sebagai salah satu sumber penggerak ekonomi dan menciptakan kesejahteraan masyarakat.

Menurut Kamus Besar Bahasa Indonesia (KBBI) ziarah merupakan aktivitas mengunjungi tempat yang oleh pandangan umum masyarakat (peziarah) biasanya diyakini mengandung unsurunsur sakral, keramat, dan suci (KBBI, 1988). Aktivitas berkunjung tersebut bisa dilakukan sebagai bentuk penghormatan, mengenang dan juga mengharapkan sesuatu untuk dirinya. Bagi umat Islam, ziarah bertujuan sebagai sarana pengingat kematian, memberikan penghormatan kepada orang yang berjasa dalam diri dan agamanya serta mengharapkan keberkahan dari doadoa yang dipanjatkan sehingga doa tersebut dapat di-ijabah oleh Allah (Chaer 2015). 
Ziarah tidak hanya dilakukan di Indonesia, tapi juga oleh masyarakat di berbagai negara muslim (Chamber-Loir and Gulliot 2007). Di seluruh dunia Muslim, tradisi ziarah ke makam orang suci dianggap sebagai kegiatan penting yang mengandung makna tidak hanya secara religius tapi juga sosial politik (Jamhari 2000). Lebih jauh ia menyatakan bahwa praktek ziarah ke makam-makam orang-orang suci Islam (wali) sesungguhnya merupakan refleksi pemahaman keislaman (Jamhari 2001). Ziarah di negara-negara Muslim adalah bagian dari tradisi perjalanan Muslim seperti haji, hijrah dan perjalanan untuk belajar dan tujuan lainnya (Eickelman and Piscatori 1996).

Tempat ziarah yang umum dikunjungi adalah kuburan. Kuburan para wali sebagai eksemplar, menjadi tempat yang istimewa bagi peziarah untuk mencari kemurahan hari, berkah dan karamah (Victor W Turner 1994: 386). Objek paling umum yang dijadikan tujuan adalah wali, para syuhada, pendiri ordo sufi, raja dan tokoh masyarakat. Alasan memilih makammakam tersebut karena diyakini bahwa di tempat tersebut pernah terjadi peristiwa miracle yang mungkin akan terjadi lagi. Kuburan yang dimaksud dalam hal ini adalah kuburan orangorang yang dianggap memiliki nama besar dan berjasa dalam bidang keagamaan. Orang-orang yang kemudian dikategorikan memenuhi kualifikasi sebagai orang suci dan diyakini memiliki kemampuan dan kekuatan mistikal (Chaer 2015).

Di makam, para peziarah biasanya melakukan ritual yang umum dilakukan sesuai dengan ajaran Islam. Beberapa ritus yang dilakukan saat ziarah biasanya berupa tahlil, al-fatihah, menabur bunga dan membawa sesaji. Ritual tersebut umum dilakukan oleh peziarah di hampir seluruh makam yang dianggap keramat (Woodward 1999). Menurut Chaer tujuan doa-doa yang dipanjatkan peziarah adalah pertama, mengingatkan seorang hamba kepada kiamat dan akhirat serta memberi gambaran berharga akan kehancuran dunia dan berbagai kerusakannya kelak juga sekarang. Kedua, mendoakan dan memohonkan ampunan kepada ahli kubur yang berada di lingkungan makam. Ketiga, sebagai sembah bekti (tanda bakti) anak kepada orang tua, baik yang masih hidup maupun yang sudah meninggal. Keempat, sebagai tanda bakti murid kepada gurunya. Kelima, sebagai tanda cinta (muhabbah), penghormatan dan penyanjungan kepada orang yang diziarahi, dan mengharap barakah dari Allah (Chaer 2015).

Dari berbagai penjelasan tersebut menunjukkan bahwa ziarah tidak terlepas dari religi atau kepercayaan seseorang. Kepercayaan akan adanya roh berimplikasi pada kegiatan ziarah sebagai bentuk penghormatan atau tanda bakti bagi orang yang sudah meninggal. Hal ini bahkan telah berlangsung sejak masyarakat Indonesia berada di masa pra Islam. Segi umum yang paling mencolok dari subsistem kebudayaan batiniah masyarakat Jawa pra Islam adalah keterlibatan terus-menerus orang yang telah meninggal dunia dalam urusan-urusan mereka yang masih hidup, wabah penyakit, malapetaka dan gagal panen dianggap sebagai akibat dari kejengkelan arwah leluhur yang tidak dihormati dengan upacara semestinya, atau sebagai akibat gangguan para arwah penasaran atau tidak bahagia, yang mungkin hanya bisa dilawan dengan perlindungan roh leluhur yang baik atau bahagia. Ekspresi ritual dari keyakinan ini merupakan inti dari semua upacara-upacara keagamaan yang diselenggarakan secara rumit bagi orang yang telah meninggal dunia dan mendoakan arwah leluhur pada setiap ritus peralihan atau pada upacara pertanian di pedesaan atau di laut (Reid 2004; Ismawati 2012). 
Menurut Koentjaraningrat, salah satu komponen religi yang paling penting adalah emosi keagamaan. Emosi keagamaan menyebabkan sesuatu benda, suatu tindakan atau suatu gagasan, mendapat suatu nilai keramat atau sacred value dan dianggap keramat. Benda-benda, tindakantindakan atau gagasan-gagasan yang biasanya tidak keramat apabila dihadapi oleh manusia yang dihinggapi oleh emosi keagamaan sehingga seolah-olah terpesona, maka benda-benda, tindakan-tindakan dan gagasan-gagasan tadi menjadi (Koentjaraningrat, 1998:376). Boleh jadi emosi keagamaan inilah yang kemudian memutuskan suatu makam dikatakan sakral atau tidak, bahkkan menjadi obyek kunjungan dalam ziarah.

Bahkan menurut Bakri, adanya emosi keagamaan tidak saja memunculkan sisi religi seseorang tapi lebih jauh emosi keagamaan ini bisa mendorong seseorang untuk mempertahankan identitasnya. Jadi, ketika emosi keagamaan muncul dengan perlakuan tidak adil atau menyinggung identitasnya, maka bukan tidak mungkin akan mendorong seseorang untuk rela melakukan apa saja untuk mempertahankan identitasnya bahkan sampai memunculkan radikalisme. Harus diakui bahwa salah satu penyebab gerakan radikalisme adalah faktor sentimen keagamaan, termasuk di dalamnya adalah solidaritas keagamaan untuk kawan yang tertindas oleh kekuatan tertentu. Tetapi hal ini lebih tepat dikatakan sebagai faktor emosi keagamaannya, dan bukan agama (wahyu suci yang absolut) walaupun gerakan radikalisme selalu mengibarkan bendera dan simbol agama seperti dalih membela agama, jihad dan mati syahid (Bakri 2004). Bisa dimungkinkan emosi keagamaan mendorong masyarakat Palembang khususnya keturunan Arab untuk lebih intens mengadakan ziarah ke makam pendahulu mereka untuk menjaga eksistensi makam tersebut.

Sesungguhnya penelitian tentang ziarah telah banyak dilakukan. Beberapa tema kajian tersebut meliputi makna, tujuan, motivasi hingga fungsi ziarah. Namun demikian, umumnya penelitian tersebut masih didominasi oleh ziarah di pulau Jawa. Seperti (Susanti 2013) mengkaji motivasi peziarah ke makam Kyai Ageng Balak. Hasil penelitiannya menemukan bahwa ada beberapa motivasi masyarakat untuk melakukan ziarah ke makam yakni ekonomi, keselamatan lahir batin, perjodohan, kekuasaan dan ketenangan batin.

Menurut Jamhari dalam penelitiannya di Bayat secara khusus menjelaskan 'Barokah dan perolehan' yang sering dijadikan sebagai tujuan masyarakat melakukan ziarah. Lebih jauh dia menjelaskan bahwa barakah adalah hasil yang didapat setelah melakukan ziarah. Barakah berasal dari Tuhan, baik langsung atau melalu perantaraan wali, yang memberikan manfaat pada ketenangan jiua. Selain itu, barakah, seperti halnya pahala yang didapat ketika melakukan ibadah, akan bermanfaat pada hari kiamat nanti. Sementara itu, "perolehan" adalah hasil yang didapat dari ziarah yang bersifat duniawi. Termasuk dalam kategori perolehan ini adalah "sesuatu" yang dapat dimanfaatkan untuk mencari kekayaan, menarik lawan jenis, sukses dalam berbisnis maupun sekolah, dan semacamnya. Jadi, bagi peziarah di Bayat, barakah bersifat suci dan mungkin saja didapat tidak kasat mata, sedangkan "perolehan" bersifat duniawi. tidak seperti barakah, perolehan munpunyai sifat "panas" yang dapat membahayakan manusia yang mencarinya (Jamhari 2001). 
Terlepas dari berbagai tujuan tersebut, Najitama malah memfokuskan fungsi sosial dari ziarah tersebut. ziarah mempunyai fungsi integrasi kelompok. Lebih jauh ada tiga model integrasi yang dia sebutkan yakni integrasi kelompok santri, integrasi kelompok bani (keluarga besar) dan integrasi keluarga kecil (Najitama 2013). Sementara itu (Priambodo 2013) yang melaksanakan penelitian pelaksanaan ziarah di Makam Pangeran Sambarnyowo di Desa Girilayu menyatakan bahwa aktivitas ziarah selain bisa menciptakan suasana ramai juga memberi peluang pengembangan ekonomi masyarakat.

\section{METODE PENELITIAN}

Penelitian ini dilaksanakan menggunakan metode kualitatif dengan teknik pengumpulan data melalui observasi, wawancara dan studi kepustakaan. Observasi dilakukan dengan mengikuti rangkaian kegiatan sebagai pengamat untuk mengetahui apa saja yang terjadi selama proses ziarah berlangsung. Selain itu, observasi ini juga memastikan bagaimana ziarah itu berproses, siapa yang terlibat dan makam yang diziarahi. Sementara wawancara dilakukan dengan melakukan tatap muka dengan panitia kegiatan, komunitas Arab Palembang dan peserta yang terlibat secara langsung dalam kegiatan. Wawancara dilaksanakan untuk memastikan dan mengkonfirmasi sebagian data yang telah diperoleh sekaligus menguatkan argumen yang telah dibangun. Selanjutnya mencari informasi dari referensi lama yang berkaitan dengan perkembangan Kota Palembang dari masa ke masa dan menguatkan data-data yang telah dikumpulkan.

Data-data yang terkumpul kemudian dirangkum, selanjutnya diorganisasikan sesuai dengan tujuan penelitian. Memilah dan memilih hal-hal pokok serta fokus pada hal-hal penting dalam penelitian serta mengesampingkan data-data yang tidak diperlukan dalam penelitian. Data yang telah dipilah kemudian diorganisasi lalu dikonfirmasi kembali baik melalui wawancara maupun melalui sumber-sumber referensi tertulis. Data yang telah diorganisasi dan memberikan gambaran yang lebih jelas terkait tujuan penelitian kemudian disajikan menjadi satu tulisan serta disimpulkan.

\section{PEMBAHASAN}

\section{Selayang Pandang Perkampungan Arab Palembang}

Berbicara tentang ziarah kubra di Kota Palembang tak bisa lepas dari peran komunitas Arab yang ada di pinggiran sungai Musi tepatnya di Kecamatan Seberang Ilir 2 dan Kecamatan Ulu. Sekalipun pada masa sekarang ziarah kubra telah banyak melibatkan luar komunitas Arab, tapi awal mula tradisi ini merupakan tradisi ruahan yang dilakukan oleh komunitas Arab ke pemakaman keluarga mereka yang sudah lebih dahulu meninggal. Komunitas Arab umumnya tinggal di pinggiran sungai musi baik seberang Ulu maupun seberang Ilir dan tidak jauh dari jembatan Ampera dan Benteng Kuto Besak sebagai ikon Kota Palembang. Sungai musi memiliki peranan penting sebagai jalur transportasi serta ekonomi sejak masa lampau. Keberadaan komunitas Arab di sungai Musi menunjukkan bahwa mereka telah memegang peran ekonomi yang cukup penting di Palembang. 
Di perkampungan Arab berdiri rumah-rumah khas Palembang yang sudah berusia ratusan tahun. Beberapa dari antara rumah masih mempertahankan keaslian dengan dinding papan yang sudah sangat tua, sementara sebagian sudah direhab dengan mengganti dinding menjadi semen. Namun demikian, rumah tersebut masih menyimpan arsitektur aslinya. Di beberapa lokasi terdapat masjid yang menjorok ke sungai. Ada juga pesantren yang sudah lama menjadi lembaga pendidikan. Akses ke perkampungan Arab bisa dilakukan dengan menggunakan transportasi darat. Fasilitas jalan sudah beraspal, walau sebagian masih ada yang berlubanglubang. Antara Seberang Ulu dan Seberang Ilir bisa dijangkau dengan menggunakan transportasi darat tapi harus melalui jembatan Ampera, sementara menggunakan transportasi air jauh lebih dekat. Biasanya untuk menyeberangi sungai Musi dilakukan dengan sampan yang tersedia. Ongkos menyeberang menggunakan pada tahun 2016 adalah Rp.5000,--

Perkampungan Arab sejak masa lampau hingga sekarang tidak mengalami perubahan yang signifikan. Hal ini terlihat dari pola pemukiman dan struktur bangunan yang masih tetap mempertahankan arsitek lama. Hanya beberapa rumah yang kemudian diubah strukturnya menggunakan batu untuk menghindari gangguan banjir. Sementara pola pemukiman masih tetap dipertahankan. Sehingga banyak bangunan yang kemudian ditetapkan sebagai benda cagar budaya. Rumah orang Arab ini biasanya membentuk semacam komplek keluarga, yang berkelompok di sekitar kediaman 'pater familias' (kepala keluarga besar). Dengan ini kewilayahan menjadi salah satu prinsip penataan kehidupan kota; setiap warga hadramaut mengawasi wilayahnya sendiri. Marga Almunawar misalnya, tinggal di 13 Ulu, Assegaf di 16 Ulu dan Almesawa di 14 ulu, sedangkan di sebelah ilir marga Alhabsyi memiliki markas di 8 Ilir, Barakah di 7 Ulu, Aljufri di 15 Ulu dan Alkaf di 8 Ilir dan 10 Ulu. Tujuh keluarga terkemuka ini pada paro kedua abad ke-19, bersama-sama membentuk elit kota Palembang (Berg 1894; Peeters 1997:18).

Selain perumahan, terdapat masjid sebagai tempat ibadah, pasar kuto serta pesantren yang telah berusia ratusan tahun. Di beberapa sudut di perkampungan Arab terdapat pemakaman seperti Kawah Tengkurap dan Kambang Koci di pelabuhan Boom baru, pemakaman Telaga Sewidak dan Babussalam serta pemakaman Gubah Duku di 8 Ilir. Menurut masyarakat setempat, pemakaman-pemakaman tersebut merupakan tanah wakaf yang dihadiahkan oleh kesultanan Palembang kepada nenek moyang mereka pada masa lalu. Pemakaman-pemakaman ini merupakan pemakaman orang-orang pertama keluarga komunitas Arab termasuk di dalamnya para penyebar pertama Agama Islam di Palembang.

\section{Munculnya Komunitas Arab dan Islam di Palembang}

Komunitas Arab, begitu juga dengan agama Islam di Palembang telah ada sejak lama. Bahkan Marsden (1783) telah mencatat dalam bukunya History of Sumatera bahwa agama Islam merupakan agama yang berlaku di seluruh kekuasaan sultan, kecuali yang sebuah distrik yang bernama Salang (Marsden 2013:433). Kedatangan bangsa Arab ke suatu wilayah memang tidak lepas dari perdagangan dan penyebaran agama Islam. Demikian halnya kedatangan mereka ke Kota Palembang. 
Keberadaan komunitas Arab di Kota Palembang tidak terlepas dari muara sungai Musi yang strategis sebagai jalur perdagangan. Pada masa kejayaannya, banyak bangsa berdatangan ke Palembang hanya untuk berniaga, termasuk Cina, India dan juga Arab. Kedatangan Arab ke Palembang sama dengan ke daerah lain untuk berdagang dan menyebarkan Agama Islam. Beberapa dari orang pertama keturunan Arab yang tinggal di palembang berasal dari Hadramaut memanfaatkan jalur dagang sungai Musi untuk memperoleh keuntungan, selanjutnya mereka menyebarkan agama Islam kepada masyarakat Palembang. Walau kedatangan mereka di Palembang tentu tidak serta-merta diterima dengan baik, Namun, satu hal yang membuat mereka kemudian diterima dengan baik adalah kemampuan berdagang dan kemapanan ekonomi membuat mereka mempunyai posisi penting dalam pandangan kerajaan pada masa itu.

Berkembangnya pertambangan timah di Pulau Bangka dan rempah telah mendorong komunitas Arab betah untuk tinggal dan menetap di Palembang. Kepiawaian mereka dalam berniaga yang memberi mereka keuntungan yang cukup besar dalam perdagangan Palembang membuat staus ekonomi dan prestise mereka semakin diakui. Sejak itu pula semakin banyak keturunan Arab tinggal di Palembang. Perkembangan ekonomi pada masa itu memang lebih ditekankan pada tambang timah dan rempah. Perkembangan ekonomi kesultanan yang ditopang tambang timah di Pulau Bangka dan ekspor lada dari pedalaman menarik sebagai tempat tinggal pedagang. Akibatnya, pada akhir kesultanan, jumlah orang Arab yang menetap di Palembang telah menjapai jumlah 500 orang lebih (Van Sevenhoven 1823:75).

Kepiawaian pedagang Arab dalam mencari keuntungan telah menempatkan komunitas Arab dalam posisi strategis dan posisi tawar yang tinggi. Hal ini mendorong keturunan arab mempunyai tempat khusus dalam hati kesultanan. Di pelabuhan Palembang, pendatang Arab sebagai mitra baru dalam perdagangan memperoleh fasilitas khusus dari Sultan Palembang, yang antara lain memperbolehkan pedagang Arab untuk membangun gudang mereka di darat (keputusan ini memberikan keunggulan dagang kepada orang Arab atas usaha dagang orang Cina, yang hanya memiliki gudang di atas rakit terapung di Sungai Musi). Juga di lingkungan keraton, orang Arab dari Hadramaut mempunyai kedudukan khusus. Orang Belanda yang pernah mengunjungi Palembang menyaksikan, bahwa jika pembesar kerajaan menghadap raja, mereka harus menyembah sampai menyentuh lantai, sedangkan orang Arab boleh duduk di kursi sisi sultan. Juga dalam segi hukum orang Arab juga hampir kebal, mereka jarang dituntut atau dihukum (Van Sevenhoven 1823:75; Peeters 1997:15).

Kekuatan ekonomi tersebut juga telah berimplikasi kemampuan keturunan Arab untuk membangun berbagai membangun berbagai hal dengan leluasa. Mulai dari fisik seperti rumah, masjid, pesantren serta tradisi juga berkembang karena senantiasa didukung oleh penguasa. Dengan meningkatnya kekuatan ekonomi mereka, pedagang Arab mulai membangun rumah besar terbuat dari Kayu besi dan tembesi, dilengkapi dengan atap genting yang besar. Rumah limas ini yang bernilai Nlg.10.000 sampai Nlg 30.000, dulu merupakan hak istimewa para priyayi; yang terkaya di antara para saudagar Arab bahkan membangun rumah dari batu, yang di zaman kesultanan adalah hak istimewa para sultan Palembang (Van Sevenhoven 1823:57-8; Berg 1894; Peeters 1997: 18). 
Ketika kesultanan Palembang dipimpin Sultan Syarif Ali. Dasawarsa antara 1840-1880 merupakan zaman kemakmuran besar untuk Koloni Hadramaut di Palembang. Pada pertengahan abad ke-19, yang tercatat sebagai pemilik kapal yang terkaya ialah Pangeran Syarif Ali bin Abubakar bin Saleh dari marga Syechbubakar. Dengan menggunakan hubungan baiknya dengan Belanda, ia berhasil membangun suatu jaringan dagang yang merentang jauh sampai ke pedalaman Palembang. Pada saat yang sama dia memperluas armada niaganya di pelabuhan palembang, sehingga pada pertengahan adab ke-19, setengah dari seluruh armada niaga Arab dimiliki oleh pangeran Ali. Di samping Syechbubakar, para pemilik kapal lain yang berasal dari marga Alkaf, Barakkah, Assegaf, bin Syihab, Almunawar dan Alhabsyi biasanya juga memiliki satu atau dua kapal pelayaran. Secara keseluruhan, masyarakat dagang Hadramaut di Palembang pada pertengahan abad ke-19, terdiri atas 20 saudagar besar dan hampir 150 pedagang menengah (ARNAS, Laporan Politik 1855:Lampiran; Peeters 1997:16)

Dengan armada niaga terdiri atas barkas, kapal layar bertiang dua dan sekunar, para saudagar Hadramaut berhasil menguasai perdagangan impor dan ekspor di Pelabuhan palembang. Pertumbuhan ekonomi yang pesat juga berpengaruh pada besarnya koloni Arab di Palembang, yang sampai pertengahan abad ke-19 masih akan menarik migran baru. Akibat ekspansi pada tahun 1885, masyarakat Hadramaut di Palembang, yang berjumlah lebih dari 2000 orang, menjadi koloni Arab yang terbesar di Hindia-Belanda sesudah Aceh (Van den Berg 1886:108: Peeters 1997:16)

Kemapanan ekonomi yang sangat menonjol membuat berbagai tampilan luar mencolok kepada orang lain. Rumah-rumah yang jauh lebih mewah dari penduduk pribumi, barang-barang serta assesories yang digunakan yang lebih berkelas. Semua itu mendorong adanya pengakuan dari penguasa kepada komunitas Arab. Sekat-sekat antara penguasa dengan masyarakat pribumi yang sangat jelas pada masa itu menjadi semakin kabur ketika komunitas Arab mampu membeli apa yang dapat dibeli oleh penguasa kerajaan pada masa itu. Pengaburan sekat-sekat tersebut juga yang mendorong terciptanya hubungan antara keluarga kerajaan dan keturunan Arab. Bahkan, pada perkembangan selanjutnya keluarga kerajaan telah menganut Agama Islam. Sejak itu Islam menjadi agama kerajaan dan hubungan dengan keturunan Arab di Palembang semakin erat. Hal ini dibuktikan dengan penyerahan berbagai tanah wakaf kepada keturunan Arab untuk dijadikan sebagai lokasi makam para pendahulunya.

Kekuatan ekonomi memang telah membantu hubungan dengan para penguasa lebih erat walau tanpa tantangan. Namun demikian hubungan erat antara penguasa kesultanan dan keturunan Arab telah memberi peluang yang besar bagi mereka untuk membangun komunitas, tradisi dan tinggal menetap di Kota Palembang. Pemberian izin untuk membangun gudang di darat merupakan satu keistimewaan yang tidak didapatkan bangsa lain, dan ini menjadi momentum semakin berkembangnya keturunan Arab di Palembang. Selain itu, keturunan Arab juga memperoleh berbagai hadiah berupa wakaf untuk memakamkam para generasi-generasi pertama Arab yang meninggal di Kota Palembang. Beberapa makam diyakini sebagai pemberian penguasa seperti gubah duku, telaga sewidak dan juga kambang Koci. 
Dalam konteks, masa Kesultanan Palembang Darussalam—seperti halnya kebanyakan Islam di Nusantara - umat Islam umumnya adalah pengikut paham Ahl al-Sunnah wal Jamâ'ah yang mengenal Islam dari sudut pandang fikih, khususnya fikih Syafi'iyyah, ditambah dengan tinjauan tauhid seperti yang terdapat dalam teologi Asy 'ariyah (Muzani, (ed), 1995: 160). Mereka ini sering diasosiasikan sebagai tradisionalis yang bercorak formalis-simbolis karena lebih menekankan ibadah formal atau ritual dalam arti sempit (ibadah mahdhah) sebagai standar utama dalam mengukur kadar keberagamaan, kesalehan dan bahkan keimanan seseorang. Ini berlawanan dengan Islam yang bercorak substantif-fungsional yang melihat Islam secara lebih komprehensif dan tidak terbatas hanya kepada ibadah dalam arti sempit semata(Adil 2014).

\section{Pemakaman Kambang Koci}

Tidak bisa dipungkiri bahwa perkembangan pemakaman di Kambang Koci secara berkala mengalami persoalan. Pembangunan pelabuhan untuk alasan mempermudah jalur distribusi sejak zaman Belanda telah dicoba. Namun keberadaan tanah wakaf dianggap menjadi penghalan pembangunan tersebut, sehingga ada keinginan untuk mengganti makam tersebut menjadi pelabuhan. Suatu ketika, pemerintah juga berniat untuk memindahkan makam tersebut, sehingga pembangunan pelabuhan Boom Baru tidak terkendala.

Beberapa masalah yang masih teringat oleh masyarakat setempat diantaranya: pemakaman kambang koci telah beberapa kali direbut oleh pihak-pihak yang merasa berkepentingan. Bermula pada masa pendudukan Belanda sekitar tahun $1913 \mathrm{M}$, melihat posisinya yang begitu strategis terletak di tepi sungai Musi, di kawasan ini dibangun Pelabuhan Boom Baru, dan 11 tahun kemudian pihak Belanda berusaha mengambil area ini, namun pihak ahli waris mempertahankannya sehingga sampailah pada satu perundingan di Batavia (jakarta) dengan dimenangkan oleh pihak ahli waris. Demikian juga pada masa pendudukan Jepang, upaya perebutan lahan pemakaman tersebut masih terjadi namun tetap tidak berhasil.

Tahun 1975 kembali terjadi sengketa dengan pihak pelabuhan sehingga terjadi pembagian luas areal pemakaman yakni dari $5000 \mathrm{~m}^{2}$ dibagi $2 / 3$ untuk pihak pelabuhan dan $1 / 3$ untuk ahli waris. Sehingga saat ini keseluruhan luas areal kambang koci tinggal $1400 \mathrm{~m}^{2}$.

Berbagai persoalan dan perebutan lahan wakaf ini sedikit banyak akan memunculkan sentimen bagi warga keturunan Arab khususnya dan muslim pada umumnya. Wakaf yang diyakini merupakan tempat pemakaman para waliyulah, habaib, dan auliyah merupakan bagian penting dalam perkembangan Islam di Palembang. Sehingga adanya konflik memicu solidaritas sesama umat islam untuk tetap mempertahankannya dengan memunculkan aktifitas yang berhubungan dengan makam yakni ziarah. Ziarah yang pada awalnya merupakan ruahan yang hanya diikuti oleh keluarga saja, kemudian beralih menjadi ziarah yang dihadiri oleh banyak muslim dari berbagai wilayah bahkan dari luar negeri.

\section{Berbagai Cerita Karomah}

Berbagai cerita karomah menjadi salah satu alasan para peziarah mengunjungi makam. Demikianlah, bagi mereka yang ziarah ke Sunan Bayat, memperoleh pahala dan barakah dari 
Allah-melalui wali Allah yang dikunjungi-merupakan tujuan utama. Sementara itu bagi mereka yang sowan dan nyekar, tujuan-tujuan yang lebih bersifat material-seperti perbaikan status sosialekonomi, pemecahan berbagai masalah, dan bahkan untuk kemenangan dalam berjudi-menjadi satu unsur penting yang melandasi kunjungan mereka ke makam Sunan Bayat (Jamhari 2000).

Karomah muncul karena seseorang diyakini merupakan orang yang istimewa, mulia dan suci. Ketika seseorang selama hidupnya berjalan di jalan yang lurus, maka besar kemungkinan akan mendapat karomah. Karomah ini kemudian diterjemahkan akan menguntungkan bagi generasi yang hidup setelah dia meninggal dunia. Sehingga, atas alasan karomah banyak orang yang mengunjungi makam berharap dapat barakah baik melalui orang yang meninggal atau atas izin yang maha kuasa. Demikian halnya diantara tokoh yang dijadikan sebagai obyek ziarah kubra. Beberapa diantara yang dimakamkan tersebut diyakini merupakan orang-orang yang memiliki karomah, sehingga layak untuk diziarahi.

Beberapa cerita karomah yang berhubungan dengan tokoh di pemakaman tersebut diantaranya tentang cerita Hubabah Sidah binti Abdullah bin Agil Al-Madihij pernah bertemu dengan Rasulullah SAW secara yaqozoh (dalam keadaan sadar) dengan iringan tetabuhan rebana dan aroma harum wewangian, sehingga seluruh perkampungan di sekitar rumahnyapun dapat mendengar suara tabuhan rebana tersebut. Hingga kini rumah tempat tinggalnya masih ada dan terawat baik.

Cerita lain dari Al-Habib Alwi bin Ahmad Al-Kaaf, seorang wali quthb yang dikenal memiliki banyak karomah. Diceritakan bahwa pernah suatu kali saat ayahnya, Habib Ahmad Al-Kaaf melakukan pelayaran ke Singapura dengan sebuah kapal. Di dalam perjalanan, kapal tersebut mengalami kebocoran. Semua penumpang panik. Ketika akan diperbaiki ternyata kapal tersebut telah ditambal dari luar dengan sebuah sandal yang menutup rapat kebocoran tersebut. Setelah sandal tersebut diambil dan dihadapkan kepada Habib Ahmad, beliau mengenali bahwa sandal tersebut adalah milik anaknya, Habib Alwi. Suatu keanehan menyelimuti hati Habib Ahmad, setibanya di Palembang, di dapati Habib Alwi, anaknya, tengah menunggunya dengan mengenakan sebelah sandal seraya meminta sandal yang satunya lagi dari ayahnya. Allah... Allah... Allah... Tatkala Habib Alwi wafat, datanglah surat dari Kampung Al-Hajrain, Hadhramaut. Setelah 6 bulan perjalanan laut dari Hadhramaut ke Palembang, surat tersebut diterima. Dan isinya adalah menanyakan siapakah waliyullah di Palembang yang wafat sehingga di Kota Tarim, Hadhramaut terjadi gempa. Dan waliyullah tersebut tak lain adalah Habib Alwi bin Ahmad Al-Kaaf.

\section{Munculnya Ziarah Kubra}

Tinggal dan menetapnya komunitas Arab di Kota Palembang telah melahirkan satu tradisi yang dikenal dengan ziarah kubra. Ziarah kubra merupakan kegiatan mengunjungi makam/ kubur, dilakukan oleh masyarakat Arab di Kota Palembang pada bulan ke delapan arab atau bulan sya'ban. Awalnya tradisi ini merupakan kegiatan rutin yang hanya dilakukan oleh anggota keluarga saja dan lebih dikenal dengan 'ruahan'. Jadi hanya dilaksanakan oleh sebagian kecil orang pada saat menjelang bulan ramadhan. 
Hubungan kesultanan Palembang dan komunitas Arab yang sangat dekat cukup menguntungkan bagi mereka. Pemberian tanah wakaf oleh kesultanan telah mendorong keluarga keturunan Arab untuk memakamkan keluarga mereka di tempat tersebut. Sehingga banyak pada alim ulama yang dimakamkan seperti di Telaga Sewidak, gubah duku, babussalam dan kambang koci yang terletak di pelabuhan Boom Baru berdekatatan dengan pemakaman kesultanan Palembang di Kawah Tengkurep. Pemakaman-pemakaman inilah yang selalu diziarahi oleh komunitas Arab pada bulan-bulan Sya'ban tiap tahunnya.

Ziarah kubra beberapa tahun belakangan tidak lagi hanya diikuti oleh keluarga komunitas Arab Palembang tapi telah diikuti oleh ribuan orang dari berbagai dareah dan suku bangsa yang ada di Indonesia. Bahkan untuk beberapa kali pelaksanaan turut dihadiri oleh alim ulama dari berbagai negara seperti Arab saudi, Yaman, Malaysia dan lain-lain. Hubungan yang terbina pada masa lampau antar keturunan Arab di palembang dengan di luar negeri telah mendorong keinginan untuk ikut terlibat dalam ziarah tersebut. Hubungan ini memang ada dua yakni hubungan karena kekerabatan serta hubungan karena pendidikan. Jasa-jasa para pendahulu telah mendorong keinginan tersebut untuk hadir tiap ada perhelatan ziarah kubra di Palembang.

Sekalipun pada awal pelaksanaan ziarah kubra adalah ruahan, namun beberapa hal telah mendorongnya menjadi kegiatan besar. Ada dua hal yang paling penting yang mendorong ziarah tersebut menjadi kubra atau besar yakni pertama, keinginan untuk mendapatkan karomah dan perolehan. Pandangan mulia kepada para pendahulu mereka (ulama dan auliyah) dan berbagai cerita karomah telah memunculkan keinginan untuk menjadi sama atau setidaknya dapat mengikuti jejak mereka. Selain itu perolehan juga menjadi harapan para peserta selagi masih hidup di dunia. Kedua, berbagai persoalan yang timbul mengenai keberadaan makam para ulama dan auliyah telah memunculkan sentimen religi (emosi keagamaan) sehingga mendorong rasa solidaritas untuk mempertahankan makam tersebut.

\section{Pelaksanaan Ziarah Kubra}

Pelaksanaan ziarah kubra dilakukan setiap tahun menjelang bulan puasa, biasanya dilakukan seminggu menjelang bulan sya'ban berakhir. Pada awalnya ziarah ini hanya dilakukan selama sehari dan obyek yang dikunjungi juga hanya pemakaman ulama dan auliyah yang ada di Kambang Koci dan Kawah Tengkurep di lingkungan pelabuhan Boom Baru. Namun seiring dengan animo masyarakat mengikuti ziarah tersebut, maka waktu pelaksanaan ziarah dilakukan selama tiga hari berturut-turut. Biasanya dimulai pada hari Jumat dan berakhir pada hari Minggu. Selain itu, jumlah makam yang dikunjungi juga semakin bertambah yakni Gubah Duku, Telaga Sewidak dan Babussalam.

Pada tahun 2016, ketika penulis meyaksikan kegiatan ziarah kubra mengunjungi beberapa titik pemakaman selama tiga hari berturut-turut. Selain itu, rangkaian acara tidak hanya sekedar ziarah, tapi juga kegiatan-kegiatan haul untuk memperingati ulama-ulama besar yang sangat berjasa dalam penyebaran agama Islam di Palembang. Rangkaian acara selama pelaksanaan ziarah kubra tersebut antara lain: 
1. Ziarah ke Pemakaman Al-Habib Ahmad bin Syech Shahab (Gubah Duku): makam ini terletak di Jalan Dr. M. Isa Lr. Gubah 8 Ilir Palembang. Diawali dari Masjid Darul Muttaqien yang berlokasi di dekat pertigaan Jalan Slamet Ryadi dan Jalan Dr. M. Isa (Pasar Kuto) menuju ke Gubah Duku. Masjid dan gubah tersebut dibangung oleh Alhabib ahmad bin syech bin shahab di atas tanah wakaf milik ayahya Al-Habib Syech bin Ahmad Shahab yang dihadiahi Sultan. Al-Habib Ahmad bin Syeikh sendiri adalah seorang alim dan banyak karomahnya. Beliau juga termasuk orang pertama yang melakukan perluasan Masjid Agung Palembang setelah Sultan Badaruddin.

2. Rauhah dan Tausiah di Pondok Pesantren Ar-Riyadh: Pondok pesantren Ar-Riyadh terletak di Jalan K.H.A. Azhari Kelurahan 13 Ulu Palembang. Didirikan oleh Habib Abdurrahman bin Abdullah Al-Habsyi. Pesantren ini merupakan tempat para santri menuntut ilmu dan telah banyak lulusan santri yang menjadi dai, guru agama dan pimpinan pondok pesantren di berbagai wilayah di Indonesia.

3. Ziarah ke Pemakaman Ulama dan Auliya di Telaga Sewidak dan Babussalam/As-Seggaf): komplek pemakaman ini terletak di 14 Ulu. Dimulai dari kediaman Al-Habib Ahmad bin Hasan Al-Habsyi yang terletak di kampung Karang Panjang (BBC) 12 Ulu Palembang, melintasi perkampungan Alawiyyin Al-Munawar hingga berakhir di Pemakaman Auliya dan Habaib Telaga Sewidak. Setelah itu dilanjutkan ke pemakaman Habaib babus-Salam (As-segaf) di Jalan Jend. A. Yani 16 Ulu Palembang.

4. Haul Al-Imam Al-Faqihil Muqaddam Tsani Al-Habib Abdurrahman As-Segaf: beliau merupakan seorang Waliyullah besar, lahir tahun 739 H di Kota Tarim. Semasa hidupnya mengkhatamkam Al-quran sebanyak 4 kali maam dan 4 kali siang serta tidak pernah tidur selama 30 tahun. Beliau beralasan tidak dapat tidur bila melihat surga di sebelah kanan dan neraka di sebelah kiri.

5. Haul Al-Habib Abdullah bin Idrus Shahab dan Al-Habib Abdurrahman bin Ahmad AlBin Hamid. Al-Habib Abdullah bin Idrus dilahirkan di Kota Tarim pada bulan Shafar 1265 H. beliau merupakan salah satu tokoh kebanggaan masyarakat Palembang. Semasa hidupnya ia mempunyai kedudukan yang tinggi disebabkan ilmu dan akhlaknya yang mulia. Sementara Ah-Habib Abdurrahman bin Ahmad Al-bin hamid adalah seorang habib yang mulia, ia banyak menimba ilmu pengetahuan dari para habaib baik di Palembang maupun di Hadramaut.

6. Acara Puncak Ziarah Kubra Ulama dan Auliya Palembang Darussalam: puncak ziarah kubra dipusatkan di Seberang Ilir Kota Palembang antara lain di Pemakaman Al-Habib Pangerah Syarif Ali bsa, Pemakaman Kawah Tengkurep dan Pemakaman Kambang Koci.

7. Wisata Bahari di Pulau Kemaro.

Kegiatan Ziarah Kubra diikuti banyak orang, banyak makam dan banyak yang menyaksikan. Menurut pengakuan salah seorang panitia, pada tahun 2016 ziarah diikuti lebih dari 10.000 orang dari berbagai daerah yang ada di Indonesia dan luar negeri. Pada jumat pagi, 
tepatnya hari pertama pelaksanaan ziarah kubra, para peserta mulai berkumpul di Masjid Darul Muttaqien. Sebagian diantaranya ikut shalat subuh, namun sebagian lagi ikut berkumpul setelahnya. Hingga pukul 08.00 wib para peserta telah hadir berkumpul di sekitar Masjid tersebut. Menunggu keberangkatan ke lokasi ziarah, dari dalam masjid berkumandang pembacaan ayatayat Al-Quran.

Sebelum keberangkatan, panitia juga para peserta menyiapkan menyiapkan berbagai peralatan untuk arak-arakan. Satu unit mobil pick up lengkap dengan sound system di dalamnya telah siap. Di atas mobil tersebut juga disiapkan kamera yang siap untuk mempublish kegiatan selama berlangsung. Di sisi yang lain, para anak-anak muda menyiapkan berbagai umbul-umbul serta bendera-bendera dengan tulisan Arab di dalamnya. Ada juga sebagian peserta yang menyiapkan hanzir marawis. Sementara di sisi yang lainnya lagi, telah tersedia tenaga pengamanan yang siap mengawal kelancaran ziarah tersebut. Ziarah di hari ini dilaksanakan di Gubah Duku sekitar $2 \mathrm{Km}$ dari titik kumpul Masjid Daruul Muttaqien. Para peserta yang semuanya laki-laki, tua dan muda seluruhnya berjalan kaki menuju pemakaman tersebut. Diperkirakan panjang arak-arakan sekitar 500 meter hingga $1 \mathrm{Km}$. Para peserta memenuhi jalan M. Isa. Diperjalanan, para peserta senantiasa mengumandangkan ayat-ayat suci sementara sebagian yang lain menyanyi dan menabuh hazir marawis. Rangkaian prosesi selama di pemakaman adalah mengucapkan salam, membaca surat yassin dan membacakan riwayat hidup para ulama dan auliyah yang ada dipemakaman tersebut. Selepas shalat jumat diadakan acara haul di pesantren Ar-Ryadh, acara haul disertai dengan kegiatan-kegiatan lain seperti pernikahan, sunatan selain dari qosidah, zikir dan tausiah.

Pada hari kedua, para peserta berkumpul di BBC di Seberang Ulu. Pada hari ke-2 ini ziarah dilakukan ke pemakaman telaga sewidak dan pemakaman Babussalam. Jarak titik kumpul dengan pemakaman telaga sewidak berkisar $2 \mathrm{Km}$, namun dengan pemakaman Babussalam mencapai $5 \mathrm{~km}$. Sebagian peziarah ada yang berjalan kaki ke pemakaman Babussalam, namun tidak sedikit yang menumpang dengan angkutan umum. Pada hari ke dua ini, para peserta sarapan di tempat titik kumpul. Mereka makan nasi kebuli atau nasi lemak dengan lauk daging kambing. Satu hal yang unik dalam kegiatan makan ini adalah sepiring berdua. Setelah pulang dari pemakaman, para peserta mengikuti haul.

Pada hari ke tiga, titik kumpul diubah lagi ke rumah bersejarah di dekat pasar Kuto Besak. Dimulai dengan sarapan bersama, lalu melakukan arak-arakan ke pemakaman. Pada hari ketiga ini merupakan puncak dari rangkaian acara ziarah kubra. Tujuan ziarah pada puncak acara ini adalah pemakaman pangeran syarif Ali, pemakaman Kawah Tengkurap serta pemakaman Kambang Koci yang ada di dalam pelabuhan Boom Baru tepatnya di Terminal Peti kemas. Pada hari ketiga ini, semua peserta yang berjumlah ribuan orang bahkan yang terbanyak dari tiga hari rangkaian acara. Selesai ziarah, para peserta selanjutnya makan bersama di komplek pemakaman. Kemudian pada sore hari, para peserta diajak untuk berwisata religi ke pulo Kemaro.

Keberadaan komunitas Arab mempunyai peran penting dalam pembangunan kebudayaan di Palembang. Peran ini semakin penting ketika pada masa lalu mampu mandiri secara ekonomi bahkan menyamai kekayaan Sultan. Kemampuan ekonomi turut mendorong hubungan baik antara komunitas Arab dengan keluarga kesultanan. Hubungan baik dengan kesultanan telah 
memberikan manfaat lain bagi komunitas Arab untuk dapat memakamkan para generasi awal dan para ulama penyebar Agama Islam di tanah wakaf yang diserahkan kesultanan kepada mereka. Para ulama ini dipercaya sebagai orang-orang suci dengan nilai-nilai karomah yang melekat di dalamnya. Peran penyebaran agama dan cerita karomah yang menyertainya telah menjadikan makam para auliyah layak dan penting untuk diziarahi.

Hal itu juga yang mendorong solidaritas umat Islam untuk tetap menjaga ketika makam tersebut menghadapi persoalan lahan dalam beberapa babak persoalan. Berbagai persoalan yang mengganggu eksistensi makam dengan adanya berbagai kepentingan akan lahan mendorong masyarakat muslim mulai mendatangi makam dan berziarah ketika ada waktu. Ziarah tersebut kemudian dipusatkan menjadi satu waktu yakni pada bulan sya'ban. Melihat berbagai persoalan tersebut kemudian tradisi ruahan berkembang menjadi ziarah kubra. Kubra berarti besar. Besar karena melibatkan banyak orang dari berbagai latar belakang dan berbagai negara.Selain untuk menjaga eksistensi makam, tradisi ini juga dimaksudkan untuk menjaga makam dari gangguan yang mungkin timbul di masa mendatang.

\section{Potensi Ekonomi}

Selama perhelatan ziarah kubra, jalan-jalan yang dilalui dengan arak-arakan ditutup sampai para peserta lewat. Di sekitar makam yang dikunjungi banyak warga membuka lapaklapak jualan. Beberapa jenis produk yang mereka jual diantaranya manik-manik, baju, kopiah, foto dan berbagai jenis perlengkapan yang berciri keislaman dan ziarah kubra. Beberapa silsilah keturunan tokoh-tokoh yang diziarahi juga ada. Selama perhelatan juga tidak ada kendala dan prosesi berlangsung dengan aman dan tertib.

Pelaksanaan ziarah kubra yang rutin diadakan setiap tahun secara langsung maupun tidak telah turut menggerakkan roda perekonomian Kota Palembang. Ribuan orang yang terlibat dalam even tahunan itu membutuhkan banyak keperluan sebagai seorang wisatawan. Mulai dari transportasi, akomodasi, kuliner, hiburan, tempat wisata lain serta pernak-pernik lainnya. Walau selama perhelatan, panitia menyediakan penginapan di rumah-rumah penduduk serta makanan. Namun para peserta banyak yang lebih memilih tinggal di hotel dan mencoba kulinerkuliner khas Palembang. Selain itu, animo masyarakat yang begitu besar tentu saja tidak semua tertampung di rumah-rumah penduduk. Demikian juga dengan makannya selama perhelatan.

Peluang meningkatkan pariwisata pada perhelatan ziarah kubra sangat besar dan pemerintahan daerah cukup jeli melihatnya. Sehingga, pemerintah daerah setempat menjadikan even tersebut masuk dalam kalender pariwisata daerah. Keterlibatan banyak orang peziarah selama tiga hari berturut-turut adalah peluang menjadi konsumen selama kegiatan berlangsung. Namun demikian, pemerintah daerah harus bisa menawarkan wisata lain yang cukup variatif mungkin bisa dipadukan atau secara terpisah dengan even ziarah kubra. Hal ini penting untuk menambah pilihan bagi masyarakat yang akan hadir di Kota Palembang menikmati kekhasan kota tersebut. Bisa pertunjukan kesenian, tempat wisata baru, kuliner dan sebagainya. Jika hal ini bisa dipadukan dengan even ziarah kubra, maka akan membuat pengunjung betah berlamalama tinggal di Palembang. 


\section{PENUTUP}

Ziarah kubra, pada awalnya merupakan ziarah keluarga (ruahan) yang biasanya dilaksanakan menjelang bulan ramadhan. Kegiatan ini dilaksanakan mengikuti tradisi Islam yang acapkali dilaksanakan pada bulan tersebut. Ruahan yang awalnya berskala kecil telah berubah menjadi ziarah kubra yang ber skala besar. Skala besar karena melibatkan ribuan orang dari berbagai wilayah di Indonesia, bahkan dari luar negeri. Perubahan tentu saja tidak bisa lepas dari motivasi masyarakat yang seringkali dalam berziarah bertujuan untuk memperoleh barakah dan perolehan. Cerita-cerita 'karomah' yang menyertai para ulama dan auliyah menjadi salah satu faktor menarik masyarakat berkunjung dan melaksanakan ziarah kubra.

Namun demikian, berkembangnya tradisi ini juga tidak bisa dilepaskan dari berbagai persoalan yang timbul berkaitan dengan keberadaan makam-makam ulama dan auliya khususnya yang terletak di Kambang Koci, Boom Baru. Sebagai makam orang suci dan dicintai Allah, serta penuh karomah, maka penting bagi masyarakatnya untuk merevitalisasi dan mempertahankan makam tersebut. Keinginan itu semakin besar ketika makam tersebut seringkali menghadapi persoalan lahan yang mengancam keberadaan makam. Kondisi ini mendorong kegiatan ziarah, sebagai salah satu cara mempertahankan keberadaan makam. Emosi keagamaan yang muncul, berkaitan dengan makam penyebaran Islam, ulama dan auliya kemudian menjadi dasar membangun solidaritas sesama muslim untuk mempertahankan makam tersebut. Kegiatan ziarah menurut mereka tidak bertentangan dengan kepercayaan dan malah menjadi media untuk mengingatkan para peziarah akan adanya akhirat, sehingga dengan demikian akan ada niat untuk bertobat dan mendekatkan diri kepada sang pencipta.

Terlepas dari latar belakang yang ada, keberadaan ziarah kubra telah menciptakan satu tradisi unik yang melibatkan banyak orang dari berbagai daerah, bahkan negara. Kegiatan yang berlangsung sekali setahun ini tidak saja bermanfaat secara religi untuk menguatkan kepercayaan, tapi juga secara ekonomi. Pelaksanaan ziarah kubra berpotensi menghidupkan roda ekonomi kota palembang, mulai dari transportasi, akomodasi dan berbagai sektor jasa lainnya. Potensi ini jugalah yang kemudian dilihat oleh pemerintah daerah setempat sebagai satu sumber devisa daerah, sehingga menetapkan ziarah kubra sebagai even rutin tahunan. Ke depan, pemerintah daerah setempat perlu untuk lebih mendukung kegiatan ini dengan berbagai infrastruktur pariwisata, sehingga mampu lebih meningkatkan kesejahteraan masyarakat.

\section{DAFTAR PUSTAKA}

Adil, Muhammad. 2014. Dinamika Pembauran Hukum Islam Di Palembang: Mengurai Isi Undang Undang Simbur Cahaya. Nurani 14 (2): 57-76.

Bakri, Syamsul. 2004. Islam Dan Wacana Radikalisme Agama Kontemporer. Dinika 3 (1): 1-12.

Berg, L. W. C. Van Den. 1894. Rechtsbronnen van Zuid-Sumatra. Bijdragen Tot de Taal, Land-En Volkenkunde V, VII-IX (3-11, 13-49, 51, 53-117, 119, 121-123, 125-151, 153, 155-197, 199203, 205-273, 275, 277-353): 277-353.

Chaer, Moh. Toriqul. 2015. Aspek Religiositas Masyarakat Peziarah Makam Shaykh Abdul Muhyi 
Pamijahan Tasikmalaya. Maraji 1 (Maret): 448-69.

Chamber-Loir, Henri, and Claude Gulliot. 2007. Ziarah dan Wali di Dunia Islam. EFEO-Coe. Jakarta: Serambi Ilmu Semesta.

Eickelman, Dale F., and James P Piscatori. 1996. Muslim Politics. Princeton, N.J.: Princeton University Press.

Ismawati. 2012. Ziarah Kubur Dalam Perspektif Budaya Dan Agama. At-Taqqaddum 4 (1): 113-28.

Jamhari. 2000. In the Center of Meaning: Ziarah Tradition on Java. Studia Islamika 7 (1): 53-90. 2001. The Meaning Interpreted. Studia Islamika 8 (1): 87-128.

Najitama, Fikria. 2013. Fungsi Sosial Ziarah Pada Masyarakat Jawa; Analisis Tradisi Ziarah Di Wonosobo. Wahana Akademika 15 (Oktober): 187-200.

Priambodo, Hengga. 2013. Tradisi Ziarah Makam Sebagai Pengembangan Ekonomi Masyarakat Di Desa Girilayu (Studi Kasus Makam Pangeran Sambernyowo Di Astana Mengadeg Desa Girilayu Kecamatan Matesih Kabupaten Karanganyar).

Susanti, Dwi. 2013. Makna Tradisi Ziarah Makam Kyai Ageng Balak Dalam Era Modernisasi (Studi Kasus Makam Kyai Ageng Balak, Desa Mertan, Kecamatan Bendosari, Kabupaten Sukoharjo, Periode Tahun 2012-2013).

Woodward, Mark R. 1999. Islam Jawa: Kesalehan Normatif Versus Kebatinan. Yogyakarta: LKiS.

Geertz, Clifford. 1992. Tafsir Kebudayaan. (Terj. Francisco Budi Hardiman). Kanisius. Yogyakarta

Ghazali, Adeng Muchtar. 2011. Antropologi Agama Upaya Memahami Keragaman Kepercayaan, Keyakinan dan Agama. Alfabeta. Bandung

Peeters, Jeroen. 1997. Kaum Tuo - Kaum Mudo Perubahan Religius di Palembang 1821-1942. (Terj. Sutan Maimoen). Indonesian-Netherlands Cooperation in Islamic Studies (INIS). Jakarta

Koentjaraningrat. 1987. Kebudayaan Mentalitas dan Pembangunan. Gramedia. Jakarta

Departemen Pendidikan dan Kebudayaan. 1988. Kamus Besar Bahasa Indonesia. Balai Pustaka. Jakarta

Geertz, Clifford. 1981. Abangan, Santri, Priyayi dalam Masyarakat Jawa. Dunia Pustaka Jaya. Jakarta

Reid, Anthony. 2004. Sejarah Modern Awal Asia Tenggara. LP3ES. Jakarta

Marsden, William. 2013. Sejarah Sumatera (Terjemahan). Komunitas Bambu. Jakarta

Sevenhoven, Jan Izaak Van. 1823. Beschrijving van de hoofdplaats van Palembang. Bataviaasch Genootschap van Kunsten en Wetenschappen. 